Sains Malaysiana 49(12)(2020): 3243-3254

http://dx.doi.org/10.17576/jsm-2020-4912-35

\title{
Microstructure and Discharge Performance of Aluminum Al 6061 Alloy as Anode for Electrolyte Activated Battery
}

(Mikrostruktur dan Prestasi Nyahcas Aloi Aluminium Al 6061 sebagai Anod untuk Bateri Teraktif Elektrolit)

\author{
Priyathashiny Pongali, Wai Yin Wong, Alvie Sin Voi Lo, Sammy Lap Ip Chan \& Kean Long Lim*
}

\begin{abstract}
Electrolyte activated battery finds its important use during natural disaster emergencies, such as floods and typhoons. Nevertheless, high corrosion rate will deteriorate the discharge performance of the battery and it is influenced by the type of electrolyte and discharge current. In this study, the corrosion and discharge performance of a commercial Al 6061 aluminum alloy as an anode are investigated at different discharge currents (0.001, 0.01, and $1 \mathrm{~mA}$ ) and in different electrolytes, namely salt water, urea, and distilled water. Scanning electron microscopy results show that electrode in salt water has the most serious corrosion, followed by that of in urea and in distilled water. These electrodeelectrolyte combinations are further investigated with potentiodynamic polarization, galvanostatic discharge, and electrochemical impedance spectroscopy (EIS) to understand their discharge potential, discharge behavior, and corrosion mechanism. Among all combinations, aluminum in water is found to have the highest discharge performance with discharge potentials ranging from 716 to $744 \mathrm{mV}$, regardless of discharge current.
\end{abstract}

Keywords: Aluminum based battery; electrolyte activation battery; emergency power generation

ABSTRAK

Bateri yang boleh diaktifkan dengan elektrolit adalah penting semasa kecemasan bencana alam, seperti banjir dan ribut taufan. Namun demikan, kadar kakisan yang tinggi akan menjejaskan prestasi nyahcas bateri dan prestasi tersebut sangat dipengaruhi oleh jenis elektrolit dan arus nyahcas. Dalam kajian ini, kadar kakisan dan prestasi nyacas aloi aluminium komersial Al 6061 yang digunakan sebagai anod dalam bateri diuji pada kadar arus nyacas yang berlainan (0.001, 0.01 dan $1 \mathrm{~mA}$ ) dan dalam elektrolit yang berlainan, yakni, air garam, urea dan air suling. Keputusan mikroskopi elektron imbasan menunjukkan elektrod di dalam air garam mengalami kakisan yang paling tinggi, diikuti dengan urea dan air suling. Kombinasi elektrod-elektrolit ini dikaji lebih lanjut dengan pengkutuban potentiodinamik, penyahcas galvanostatik dan spektroskopi impedans elektrokimia untuk memahami keupayaan nyahcas, kelakuan nyahcas dan mekanisme kakisan. Antara semua kombinasi, aluminium di dalam air didapati menunjukkan prestasi nyahcas yang tertinggi dalam julat 716 to $744 \mathrm{mV}$, tanpa mengira arus nyahcas.

Kata kunci: Bateri berasakan aluminum; bateri yang diaktifkan dengan elektrolit; penjana kuasa kecemasan

\section{INTRODUCTION}

The access to electricity in the aftermath of natural disasters especially floods and typhoons can be prolonged, thus devices that can store energy indefinitely and generate electricity on demand are highly sought after. While most batteries could be a solution to this issue, they self-discharge considerably overtime. Therefore, one of the many ways to address this self-discharge issue is by separating the electrolyte from the battery cell during storage. Nonetheless, the electrode of this electrolyte activated battery should be stable in air, easily activated with electrolyte, long-lasting, low self-corrosion, light- weighted, affordable, disposable and recyclable (Ilya et al. 2017; Mokhtar et al. 2015). The basic reaction of a battery is the exchange of electrons between cathode and anode electrodes. The cathode is where the reduction occurs whereas oxidation takes place at anode. It is also applicable to electrolyte activated batteries.

Among the different metals, aluminum-based electrode is a good candidate for this type of battery because it is light, a high negative standard potential of $1.676 \mathrm{~V}$ vs. SHE, high theoretical energy density of $8076 \mathrm{Wh} \mathrm{kg}^{1}$ (Pino et al. 2015), and abundant in the Earth crust (third most abundant element after $\mathrm{O}$ and $\mathrm{Si}$ ) (Raptis 
et al. 2018). In addition to that, it is low production cost and easy recycling processes have contributed to price stability and affordability (Pino et al. 2016). The 6000 group of aluminum alloys contain magnesium and silicon as major alloying elements and is widely used for automotive and aerospace structures due to their good extrudability, weldability and excellent corrosion resistance. Aluminum 6061 is a typical alloy of this group and contains $\mathrm{Mg}-\mathrm{Si}-\mathrm{Cu}$ alloying elements. The high level of alloying elements added to increase the strength, leads to the formation of large constituent intermetallic particles during casting. These particles are too large to be greatly affected by subsequent thermomechanical processing (Nikseresht et al. 2010). Aluminum alloy reinforcement with $\mathrm{SiC}$, report lower corrosion resistance for the composites compared to matrix alloys (Wang et al. 2014a). On the other hand, aqueous electrolyte is used as an ionic conductor and activator because of its availability, fluidity and high ionic conductivity (Mokhtar et al. 2018, 2015). For instance, salt water (Abdulrehman et al. 2015; Deng et al. 2016; Hongyang et al. 2009; Kim et al. 2019, 2016; Kobashi et al. 2009; Li et al. 2002; Liu et al. 2017; Pino et al. 2015; Shi et al. 2017a, 2017b; Tang et al. 2018; Vuorilehto et al. 2003; Wang et al. 2014b; Wen et al. 2016; Yu et al. 2015) is one of the most commonly used electrolytes in this type of battery. Nonetheless, aluminum formed an oxide film on the surface when in contact with an aqueous solution, preventing the active dissolution of $\mathrm{Al}$ and thus less energy can be extracted from the electrochemical reaction (Pino et al. 2016).

This paper provides a detailed study on the corrosion resistance and discharge performance of $\mathrm{Al}$ anode with respect to salt water, urea and water at different discharge currents. These electrolytes were selected because they are easily available in every household and more relevant to be used for power generation during natural disaster. The discharged performance and corrosion behaviours were investigated by varying the discharged current to simulate its usage in different small appliances.

\section{MATERIALS AND Methods}

\section{ELECTRODES AND MATERIALS}

Aluminum alloys (Al 6061) with the thickness of $2 \mathrm{~mm}$ are cut into $3 \times 3 \mathrm{~cm}^{2}$ area and used as the anode materials. The samples were polished with emery paper (grade 200 - 800) and then cleaned with distilled water and acetone. The cathode was prepared by grinding the manganese (IV) oxide $\left(\mathrm{MnO}_{2}\right)$ powder together with carbon black and polyvinylidene fluoride (PVDF) in the ratio of 15:4:1 by weight. Next, N-Methyl-2-Pyrrolidone (NMP) solution was added to the powder mixture to produce a medium viscous paste. Subsequently, the $\mathrm{MnO}_{2}$ composite paste was loaded on the nickel foam. Three different electrolytes in a $100 \mathrm{~mL}$ volumetric flask were prepared: $1 \mathrm{M}$ of $\mathrm{NaCl}$ solution (R\&M Malaysia), $1 \mathrm{M}$ of urea solution (R\&M Malaysia) and distilled water.

\section{MICROSTRUCTURE CHARACTERIZATION}

To investigate the microstructure of the experimental alloys before and after galvanostatic discharge test, a Scanning Electron Microscope (Carl Zeiss VP-SEM EVO MA 10) instrument was utilized. The chemical composition of the corroded products on the alloy surface were characterized and mapped via energy-dispersive $\mathrm{X}$-ray spectroscopy (EDX) after performing the discharge measurement at different current discharge.

\section{ELECTROCHEMICAL TESTS}

The polarization curves and electrochemical impedance spectroscopy (EIS) of experimental alloy anodes were measured with a Metrohm Autolab (NOVA) system in a three-electrode system, comprising of a working electrode, a counter electrode and a reference electrode (Silver chloride). All acquired data was processed with the Nova 1.10 software. The electrodes were immersed in the electrolyte for $5 \mathrm{~min}$ to stabilize the electrodes and to allow good contact between electrodes and electrolyte before the measurement of polarization curves. Polarization curves were recorded in the potential range of -0.5 to $+1.0 \mathrm{~V}$. The cut-off potential for all cases was set at $0.0 \mathrm{~V}$. Electrochemical impedance spectroscopy (EIS) is an effective method to investigate the discharge behavior and corrosion mechanism of aluminum anode. The EIS results were fitted with an equivalent circuit in a Nyquist plot using the Nova software. Similarly to the measurement of the polarization curve, the electrochemical impedance spectra (EIS) measurements were recorded after immersing the electrodes in electrolytes for $5 \mathrm{~min}$. The perturbation potential of $5 \mathrm{mV}$ with a frequency range from $0.01-100 \mathrm{kHz}$ was used in this measurement. Finally, a single cell with $\mathrm{Al}$ as the anode, $\mathrm{MnO}_{2}$ as the cathode and gauze swab as the separator, was assembled for discharge performance measurement with a galvanometer. The effect of discharge current $(0.001$, 0.01 , and $1 \mathrm{~mA}$ ) was investigated.

\section{RESULTS AND DISCUSSION}

\section{MORPHOLOGY AND MICROSTRUCTURE OF ALUMINUM ANODE}

Figure 1 shows the morphology and microstructural changes of aluminum anode before (a) and after the discharge test in different electrolytes at different discharge currents $(b-j)$. The respective EDX element mappings were taken and reported in Figure 2, where ' $\mathrm{K}$ ' represents the $\mathrm{K} \alpha \mathrm{X}$-ray photon generated by the electron transitions from the L-shell to the K-shell. Both Figures 1 and 2 are complimentary to each other. Various forms of corrosion morphology were formed on the surface of the alloys upon the discharge test. It can be seen that the corrosion products increased with discharge current, except for the samples in urea electrolyte. Depending on 
the electrolyte, the corrosion mechanism of aluminum anode is a competition between self-corrosion and dissolution of anode into electrolyte. Generally, selfcorrosion is more dominant at low discharge current and more prone to pitting corrosion.
The fundamental reactions of the corrosion of aluminum are shown in (1), (2) and (3).

Oxidation at the anode:

$$
2 \mathrm{Al} \rightarrow 2 \mathrm{Al}^{3+}+6 \mathrm{e}^{-}
$$
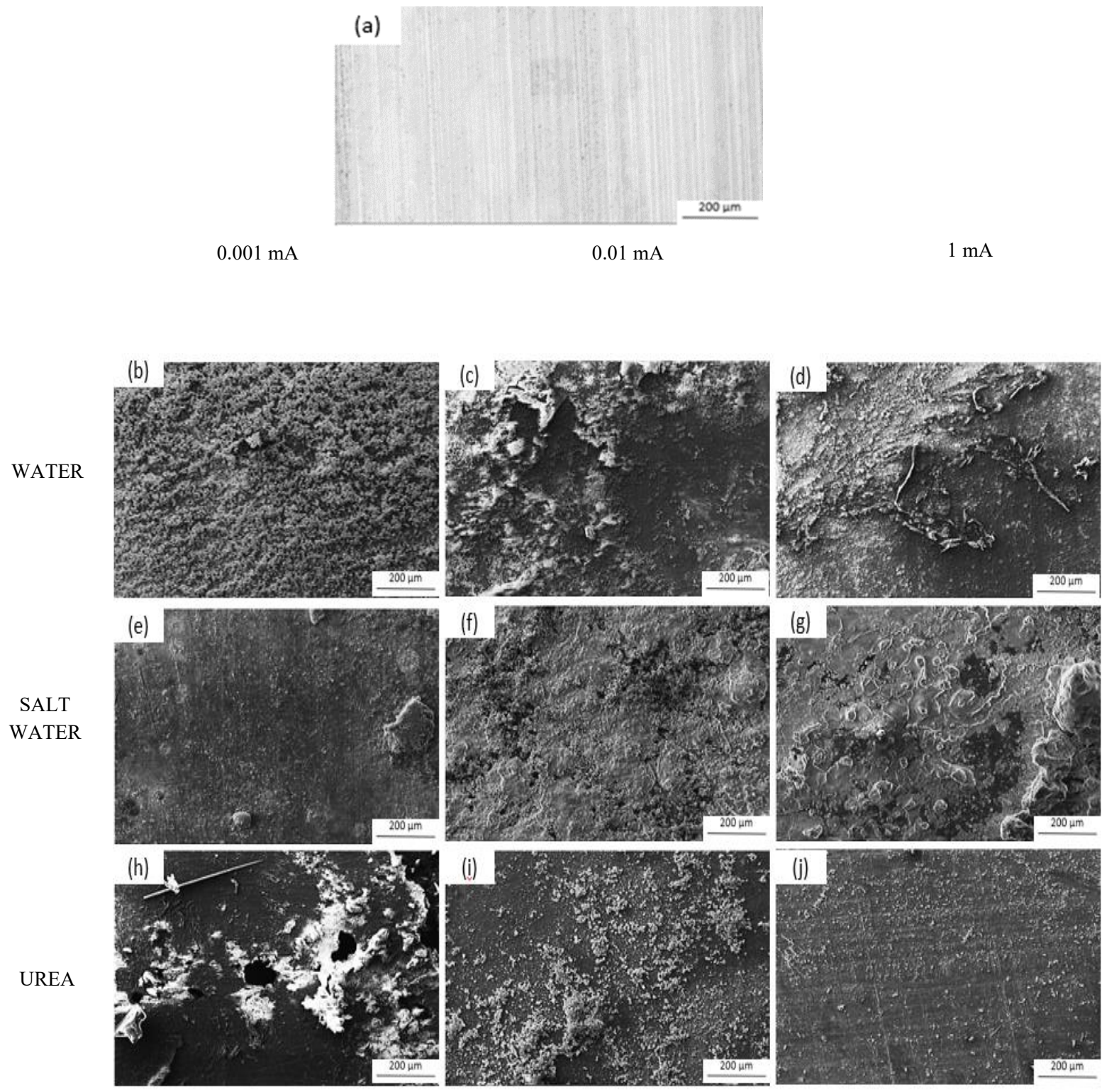

FIGURE 1. Surface morphology of aluminum anode before (a) and after (b-j) the discharge test in different electrolytes at different discharge current

Reduction at the cathode:

$$
3 / 2 \mathrm{O}_{2}+3 \mathrm{H}_{2} \mathrm{O}+6 \mathrm{e}^{-} \rightarrow 6 \mathrm{OH}^{-}
$$

or

$$
6 \mathrm{H}^{+}+6 \mathrm{e}^{-} \rightarrow 3 \mathrm{H}_{2}
$$

Aluminum corrosion results in the formation of alumina $\mathrm{Al}(\mathrm{OH})_{3}$, which is insoluble in water and precipitates as a white gel. The overall reaction of pitting corrosion on aluminum is represented by (4) (Mroczkowska et al. 2019):

$$
2 \mathrm{Al}+3 \mathrm{H}_{2} \mathrm{O}+3 / 2 \mathrm{O}_{2} \rightarrow 2 \mathrm{Al}(\mathrm{OH})_{3}
$$

At a low discharge current of $0.001 \mathrm{~mA}$, sample in water electrolyte shown in Figure 1(b) formed a 
protective layer consists of aluminum hydroxide and aluminum oxide (Leisegang et al. 2019) as described in (5), where the corrosion products were granular and small. The corrosion products in the form of oxide and hydroxide corresponded with the EDX results in Figure 2(b), where oxygen were distributed evenly on the aluminum surface. It is noted that EDX technique is unable to distinguish the oxide and hydroxide products due to the low detectability of hydrogen with X-ray. This observation may be caused by random but uniform nucleation on the surface as well as slow growth rate of corrosion products at low current, which allows the corrosion products to attach and crystalline on top of each other. At a higher discharge current, the corrosion rate is higher which leads to the formation of uneven corrosion products on the anode surface caused by the detachment of corrosion film (Zhang et al. 2017), exposing more new surfaces for further corrosion as shown in Figure 2(d), where the elemental distribution of Al was slightly increased.

$$
\mathrm{Al}+3 \mathrm{H}_{2} \mathrm{O} \rightarrow \mathrm{Al}(\mathrm{OH})_{3}+3 \mathrm{H}_{2}
$$

On the other hand, the corrosion of sample in salt water electrolyte was contributed by both hydroxide and chloride ions. When aluminum is wetted with salt water, corrosion happens initially. At low discharge current, more oxygen content is consumed due to the dissolution and precipitation of aluminum. Unexpectedly, the concentration of chloride ion on the anode surface is low at low discharge current, indicating the corrosion at this discharge current is predominately self-corrosion. Nevertheless, chloride ion is predominantly responsible for the corrosion of aluminum in salt water at higher discharge current because the presence of aggressive chloride ions leads to the initiation and development of pitting corrosion and cause the dissolution of the $\mathrm{Al}(\mathrm{OH})_{3}$ film when adsorbed at electrode surface, as can be seen in both Figure 2(e) and 2(f), where the concentration of $\mathrm{Na}$ and $\mathrm{Cl}$ was detected on the anode surface was high. The presence of aggressive chloride ions leads to the initiation and development of pitting corrosion and causes the dissolution of the $\mathrm{Al}(\mathrm{OH})_{3}$ film (Shi et al. 2017a; Wen et al. 2016) as can be seen from Figure 1(e) to 1(f).

Interestingly, the samples in urea electrolyte started with severe pitting corrosion at low discharge current as shown in Figure 1(h) and shifting to the least corroded surface at high discharge current in Figure 1(j). While the nitrate ions should passivate the anode surface at a high concentration of urea (1M) (Starostin et al. 2016), it seems that the nitrate ions penetrate into the aluminum anode at a low discharge current. One of the possibilities would be low discharge current results in the slow formation of the passive film on the surface, which then allows more time for the nitrate ions to further diffuse into the anode to propagate the self-corrosion and pitting effect. While at higher discharge current, the fast formation of a uniform passive film reduces the site-specific attacked by nitrate ions and chloride ions. This hypothesis was confirmed with the high concentration of oxygen around the corrosion pits as shown in Figure 2(h), which may be contributed by the nitrate ions and oxide ions. At higher discharge current, the micrographs in Figure 1(i) and 1(j) showed that a smooth and uniform layer of passive layer was formed on the anode surface with some excess small crystalline oxide particles attached to it.

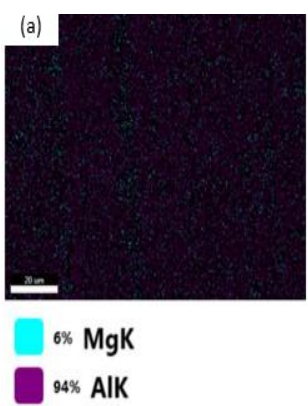

$0.001 \mathrm{~mA}$

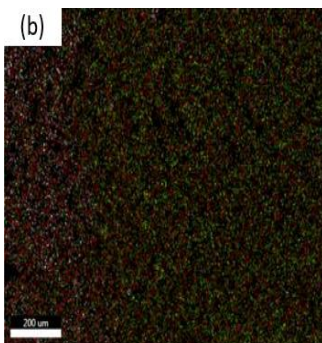

$$
\begin{aligned}
& \text { 49\% O K } \\
& 9 \% \text { MgK } \\
& 41 \% \text { AlK }
\end{aligned}
$$

$0.01 \mathrm{~mA}$
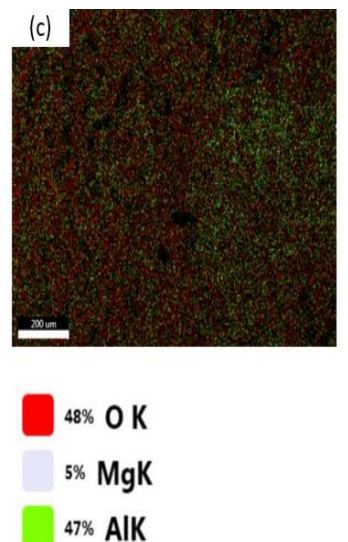

$1 \mathrm{~mA}$

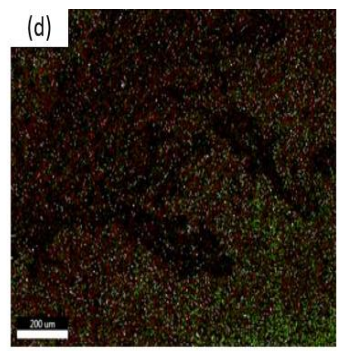

$45 \%$ OK

$2 \% \mathrm{MgK}$

${ }_{52 \%}$ AlK 


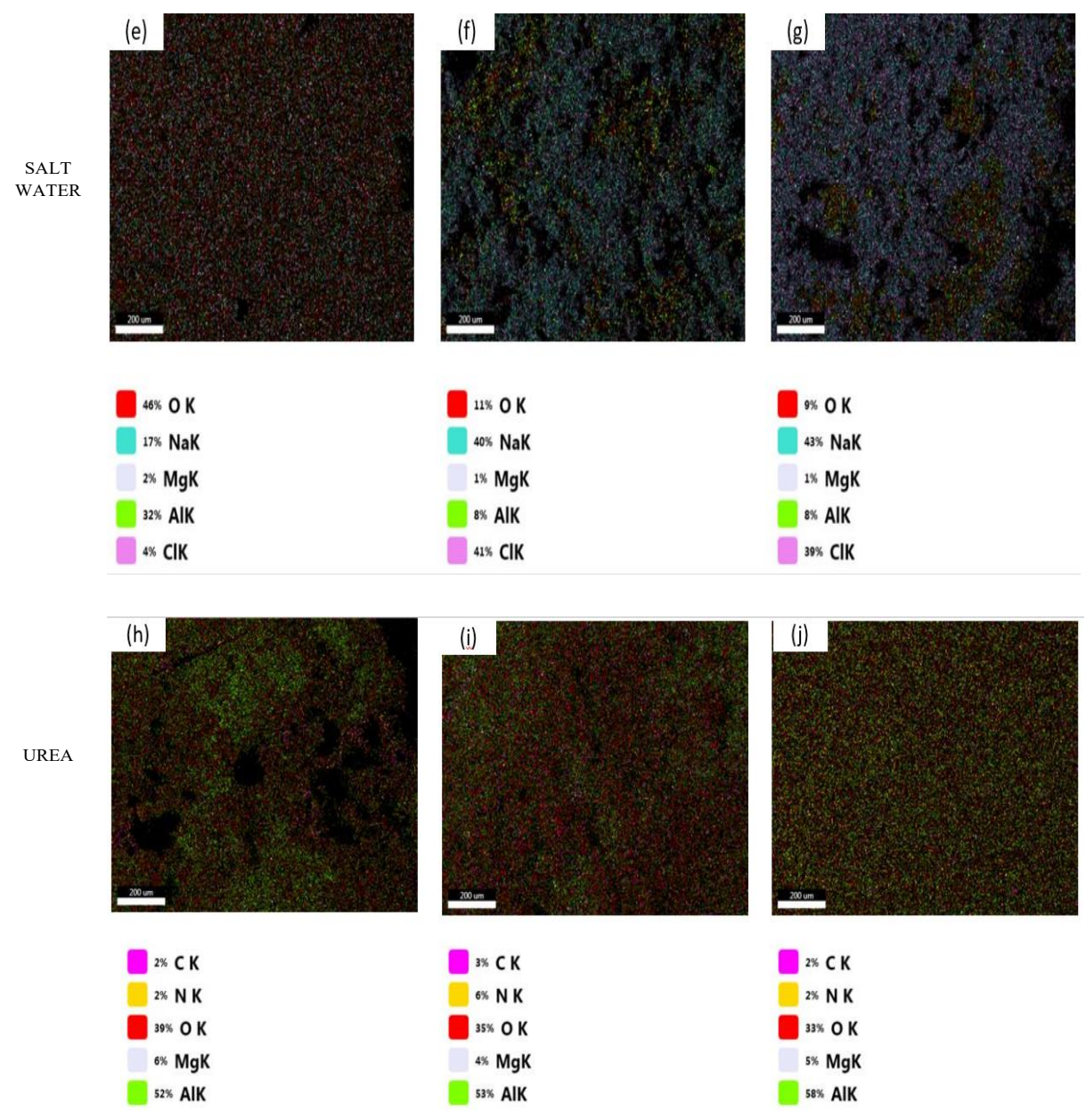

FIGURE 2. The element mapping of aluminum anode and corrosion products in different electrolytes at different discharge current

\section{POTENTIODYNAMIC POLARIZATION}

Figure 3 shows the polarization curves of aluminum alloys tested in water, salt water, and urea. All these curves composed of two branches, which are the cathodic branch and the anodic branch; and their shapes are not symmetrical. The corrosion potential, cathodic Tafel slope, corrosion current density and corrosion rate obtained from the polarization measurement are summarized in Table 1.

The corrosion potentials of aluminum alloy in water, salt water and urea are $-1.2685,-0.64843$, and -0.91211 $\mathrm{V}$, respectively. The corrosion potential of aluminum alloy in salt water is more positive than the rest of the samples, one may be misled to conclude that aluminum anode in salt-water should be the most corrosion-resistant. However, the corrosion potential is the measurement of the thermodynamic driving force for the anode to dissolve into a solution (Brantley et al. 2017). Although the corrosion potential maybe large, the severity of corrosion is very much affected by the corrosion kinetic (Ropital et al. 2011). Therefore, the corrosion of aluminum anode in salt water is more severe and at a higher rate, judging from its corrosion rate of $0.1928 \mathrm{~mm} /$ year, which is at least 20 -fold higher and 200-fold higher than that of aluminum in urea and water, respectively. The Tafel slope is defined using (6), in which $\mathrm{n}$ is the value of the cathodic potential minus the corrosion potential, $a_{c}$ is the intercept, $b_{c}$ is the Tafel slope for the cathodic branch, and $\mathrm{J}$ is the corresponding cathodic current density (Shi et al. 2017a; Wen et aal. 2016). Due to the fact that the positive and negative signs of a current density in a potentiostat represent the state of reactions only, the modulus value of current density was used in the calculation.

$$
\mathrm{n}=\mathrm{a}_{\mathrm{c}}+\mathrm{b}_{\mathrm{c}} \log (1 \mathrm{Jl})
$$


The corrosion current densities of aluminum in different electrolytes show a similar trend, where aluminum in salt water with a corrosion current density of $1.6594 \times 10^{-5}$ A.cm ${ }^{2}$ is at least 2-fold higher and 20fold that of aluminum in urea and water, respectively. Such low corrosion rate of aluminum anode in water is expected to reduce the extractable energy significantly because the combination of dissolved $\mathrm{Al}^{3+}$ and $\mathrm{OH}^{-}$form a protective precipitate, $\mathrm{Al}(\mathrm{OH})_{3}$, on anode surface (as shown in Figure 1), inhibiting the anode from corrosion and dissolution (Wen et al. 2016). The corrosion rate is obtained from the test. The discharge behavior will be further confirmed and discussed in the galvanostatic discharge section.

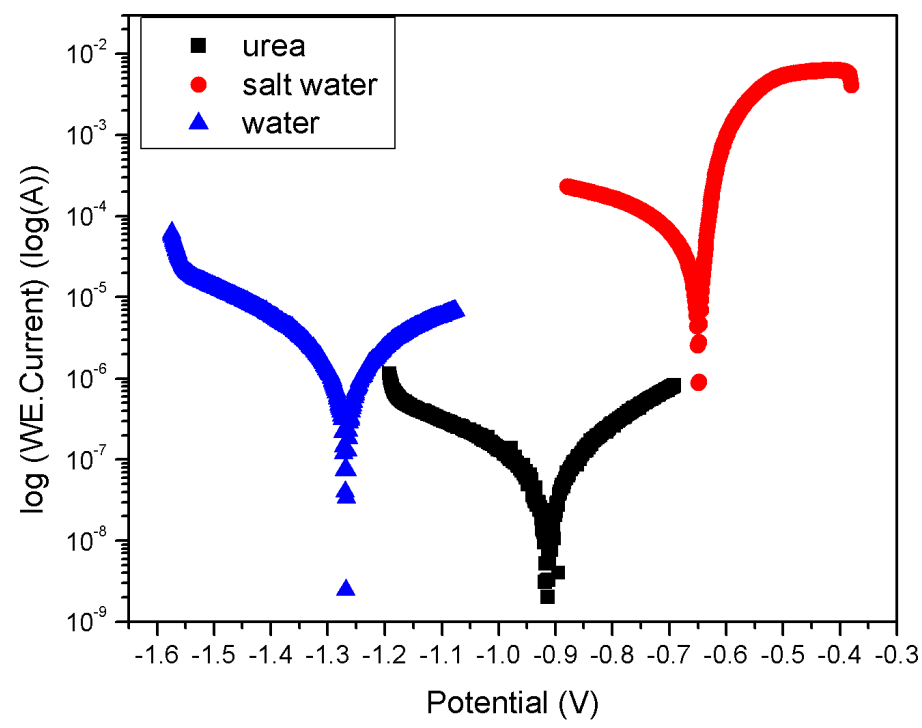

FIGURE 3. Polarization curve of commercial aluminum alloy anode and manganese dioxide cathode using water, salt water and urea solution as electrolytes

TABLE 1. Corrosion parameters of aluminum alloys tested in water, salt water and urea obtained from polarization measurements

\begin{tabular}{lcccc}
\hline Electrolyte & Corrosion potential $(\mathrm{V})$ & $\begin{array}{c}\text { Tafel slope, } b_{\mathrm{c}} \\
\left(\mathrm{m} . \mathrm{V} \cdot \mathrm{dec}^{-1}\right)\end{array}$ & $\begin{array}{c}\text { Corrosion current density, J corr } \\
\left(\mathrm{A} . \mathrm{cm}^{-2}\right)\end{array}$ & $\begin{array}{c}\text { Corrosion rate }(\mathrm{mm} / \\
\text { year })\end{array}$ \\
\hline Water & -1.2685 & 0.59468 & $6.4807 \times 10^{-7}$ & 0.0009 \\
Salt water & -0.64843 & 0.13189 & $1.6594 \times 10^{-5}$ & 0.1928 \\
Urea & -0.91211 & 0.48703 & $7.4677 \times 10^{-6}$ & 0.0075
\end{tabular}

\section{ELECTROCHEMICAL IMPEDANCE SPECTROSCOPY}

Electrochemical impedance spectroscopy (EIS) measurement is performed to investigate the discharge behavior and corrosion mechanism of aluminum anode via fitting its Nyquist plot with an equivalent circuit model, as shown in Figure 4. The equivalent circuit consists of a solution resistance $\left(\mathrm{R}_{\mathrm{s}}\right)$, which is the intercept on the $\mathrm{X}$-axis at the higher frequencies in series of two parallel circuits, i.e. a charge transfer resistance $\left(R_{t}\right)$ in parallel to a constant phase angle double layer $\left(\mathrm{CPEt}_{\mathrm{dl}}\right)$ and a film resistance $\left(R_{f}\right)$ in parallel to a film capacitance $\left(\mathrm{CPEf}_{\mathrm{dl}}\right)$ (Abdulrehman et al. 2015). The parallel connection $R_{t}$ 
and $\mathrm{CPEt}_{\mathrm{dl}}$ are corresponding to the diameter of large capacitive loop in the high frequency region of Nyquist plot in Figure 5 (Wen et al. 2016). Whereas, the $R_{f}$ and $\mathrm{CPEf}_{\mathrm{dl}}$ at the low frequency region are associated with the corrosion film. Constant phase angle double layer $\left(\mathrm{CPE}_{\mathrm{dl}}\right)$ was used instead of capacitance double layer to the accommodate the inhomogeneity in electrochemical system. The total of these resistances is the polarization resistance, $R_{p}$, which is represented in (7) (Starostin et al. 2016).

$$
R_{p}=R_{s}+R_{t}+R_{f}
$$

The fitted parameters are listed in Table 2 . Polarization resistance of aluminum anode in salt water is the lowest among all, which indicates that the overall corrosion resistivity of this electrode-electrolyte combination is the lowest. A further analysis into two main resistance components that are responsible for the corrosion mechanism of the anode, both $R_{t}$ and $R_{f}$ have a similar trend where the values of each resistance is in the order of aluminum in water $>$ urea $>$ salt water. The trend of $\mathrm{R}_{\mathrm{t}}$ components, which are the interface resistivity between the electrode and electrolyte, is in agreement with the reciprocal of corrosion current density, where the lower the charge transfer resistivity, the higher corrosion current density is, hence the higher the corrosion rate is. Meanwhile, the $\mathrm{R}_{\mathrm{f}}$ components also share the similar trend as that of $\mathrm{R}_{\mathrm{t}}$ components, suggesting that the dissolubility of inhibitor film on the aluminum surface is in the order of water $>$ urea $>$ salt water. In addition, the $\mathrm{CPEf}_{\mathrm{dl}}-\mathrm{T}$ values can also be correlated to the film thickness of protection film (Kushima et al. 2015) which includes two parameters $\mathrm{Y}_{\mathrm{dl}}$ and $\mathrm{n}$ as shown in (8). According to software, the iteration was converge and the $\chi^{2}$ values showed less than 0.01 , indicating the model was well fitted with the measurements. Thus, the data is valid to make an equivalent circuit. The low $\mathrm{C}_{\mathrm{dl}}$ value for the aluminum alloy indicates the formation of relatively thick and dense protective film on the alloy surface. As expected, the aluminum alloy tested in salt water obtains the highest $\mathrm{C}_{\mathrm{dl}}$ value and aluminum alloy tested in water obtains the lowest value. In the present study, it is also seen that increasing $\mathrm{R}_{t}$ is accompanied by the reduction of $\mathrm{C}_{\mathrm{dl}}$ due to the totally different corrosion behaviors ( $\mathrm{Yu}$ et al. 2015). The parallel connection of $\mathrm{CPEt}_{\mathrm{dl}}$ and $\mathrm{R}_{\mathrm{t}}$ is employed to illustrate the high- frequency capacitive loop, and $\mathrm{CPEt}_{\mathrm{dl}}$ normally includes two parameters, i.e. $\mathrm{Y}_{\mathrm{dl}}$ and $\mathrm{n}(0<\mathrm{n}<1)$. The constant phase angle element $(\mathrm{CPE})$ is introduced to describe the non-ideal capacitive behavior, and it can also compensate the nonhomogeneity in electrochemical system (Yu et al. 2015). The parameter Y can be converted into the capacitance via (8), in which $\mathrm{w}_{\mathrm{m}}$ is the angular frequency as the imaginary part $\left(Z_{i m}\right)$ reaches a maximum value. A larger $\mathrm{CPE}_{\mathrm{dl}}-\mathrm{T}$ value indicates the inhibitor film on electrode surface is thinner, hence has a poor corrosion inhibition. The values of $\mathrm{R}_{\mathrm{t}}$ that are larger than $R_{f}$ also indicate that all three electrode-electrolyte combinations are predominantly by activation-controlled corrosion (Wen et al. 2016).

$$
\mathrm{C}=\mathrm{Y} \cdot\left(\mathrm{w}_{\mathrm{m}}\right)^{\mathrm{n}-1}
$$

Similarly, the parallel connection of $\mathrm{R}_{\mathrm{f}}$ and $\mathrm{CPEf}_{\mathrm{dl}}$ is used to model the low-frequency capacitive loop, which is a result of the protection film on the electrode surface (Feng et al. 2016; Yu et al. 2015). In addition, (9) was employed to calculate the time constant $(\tau)$ (Wang et al. 2014a).

$$
\tau=\mathrm{C} . \mathrm{R}
$$

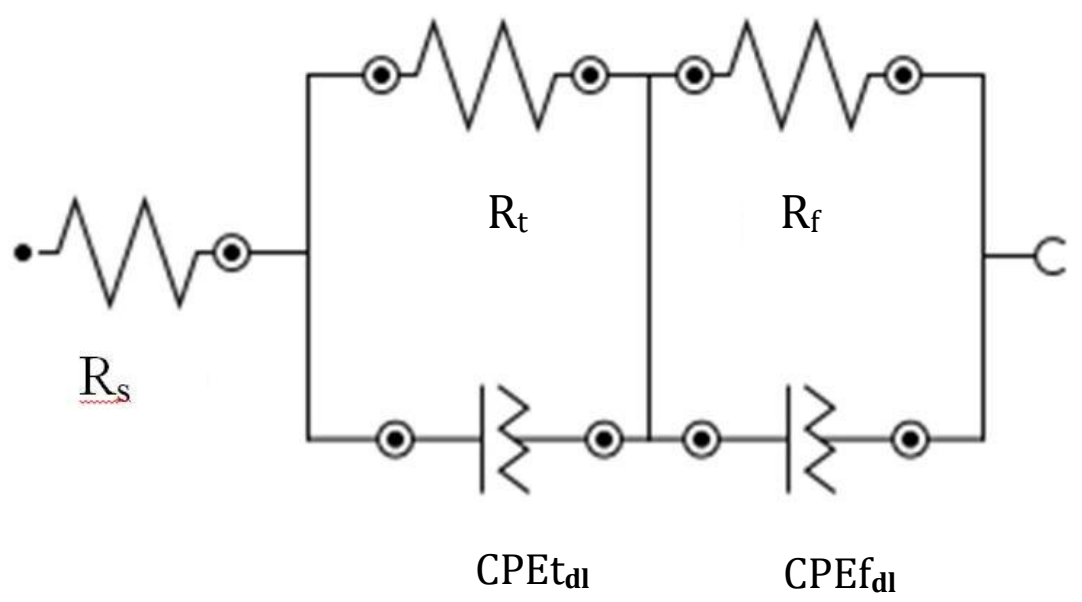

FIGURE 4. Equivalent circuit for fitting EIS of the aluminum alloy tested in different electrolytes 


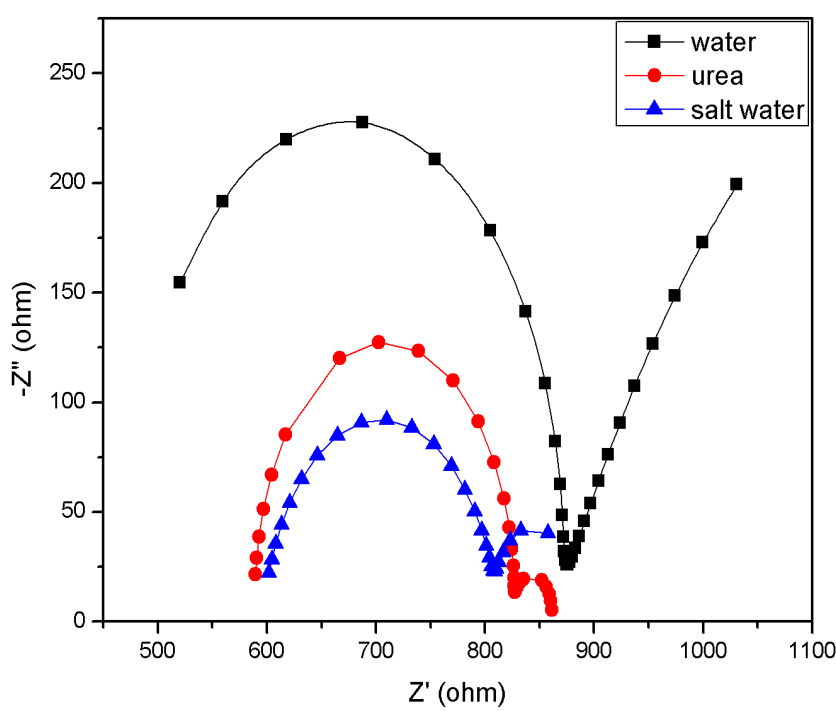

FIGURE 5. Nyquist plots after immersion of different electrolytes

TABLE 2. Electrochemical parameters of aluminum alloys tested in water, salt water and urea obtained by fitting the electrochemical impedance spectra

\begin{tabular}{lcccccc}
\hline Electrolyte & $\mathrm{R}_{\mathrm{s}}(\Omega)$ & $\mathrm{R}_{\mathrm{f}}(\Omega)$ & $\mathrm{CPE}_{\mathrm{dl}} \mathrm{P}\left(\Omega^{-1} \cdot \mathrm{cm}^{2} \cdot \mathrm{s}\right)$ & $\mathrm{CPE}_{\mathrm{dl}}-\mathrm{T}$ & $\mathrm{R}_{\mathrm{t}}(\Omega)$ & $\chi^{2}$ \\
\hline Water & 492.77 & 154.91 & $2.933 \times 10^{-7}$ & 1.003 & 394.25 & 0.00455 \\
Salt water & 594.46 & 34.70 & $2.3326 \times 10^{-5}$ & 0.997 & 209.92 & 0.00765 \\
Urea & 593.01 & 51.55 & $2.0527 \times 10^{-6}$ & 1.001 & 227.57 & 0.00957 \\
\hline
\end{tabular}

\section{GALVANOSTATIC DISCHARGE}

The discharge performance illustrated in Figure 6, was measured on a single cell at different discharged currents, which are (a) at open circuit potential (OCP, i.e. 0 A), (b) $0.001 \mathrm{~mA}$, (c) $0.01 \mathrm{~mA}$, and (d) $1 \mathrm{~mA}$, and the corresponding discharge parameters are listed in Table 3. The measurement OCP was to identify the initiation and propagation of corrosion in different electrolytes ( $\mathrm{Li}$ et al. 2016; Tang et al. 2019). The average OCP values shifted to a lower value in the rank of salt water $<$ urea $<$ water. The discharge curve of water electrolyte fluctuates throughout the measurement because of the unsteadiness between dissolution of $\mathrm{Al}$ and formation of corrosion products on Al surface. Contrary, both urea and salt water exhibited a considerably stable and enhanced active dissolution because the free ions in the electrolytes promote the dissolving-reprecipitation mechanism. This mechanism can be deduced from the observation of EDX in Figure
2, particularly the chlorine elements. Unfortunately, light element such as nitrogen is not obvious with $\mathrm{x}$-ray measurement

As a whole, the average discharge potential of all electrode-electrolyte combinations at $0.001 \mathrm{~mA}$, except aluminum-salt water, decreased when the discharge current is increased to $0.1 \mathrm{~mA}$ and slightly increased when the discharge current is further increased to $1 \mathrm{~mA}$. The general decrement of discharge potential values at higher discharge current is because of the internal resistance, where part of the potential energy from the anode is converted into heat during discharge and formation of corrosion products. It should be noted that the higher the discharge potential value (larger overpotential) is, the stronger the discharge activity (Kushima et al. 2015; Starostin et al. 2016). In other words, a stronger discharge activity leads to higher utilization efficiency (Deng et al. 2016). Electrode-electrolyte combination that has a higher utilization efficiency, 
provides more electrons per unit mass to generate current when used as the anode for an electrolyte-activated battery (Wen et al. 2016), which is an important feature for $\mathrm{Al}$ as an anode for electrolyte-activated battery. Hence, it can be concluded that the aluminum alloy tested in water and urea exhibited better discharge performance.

TABLE 3. Galvanostatic discharge parameters of experimental alloys using different electrolytes

\begin{tabular}{|c|c|c|c|c|}
\hline Electrolyte & Discharge current (mA) & Starting potential $(\mathrm{mV})$ & Average potential (mV) & $\begin{array}{l}\text { Open circuit voltage } \\
(\mathrm{mV})\end{array}$ \\
\hline \multirow{3}{*}{ Water } & 0.001 & 895.9 & 744.3 & - \\
\hline & 0.01 & 759.2 & 716.1 & - \\
\hline & 1 & 797.9 & 729.4 & 635.9 \\
\hline \multirow{3}{*}{ Urea } & 0.001 & 578.4 & 598.9 & - \\
\hline & 0.01 & 1016.2 & 586.5 & - \\
\hline & 1 & 1207.8 & 651.6 & 609.2 \\
\hline \multirow{3}{*}{ Salt water } & 0.001 & 856.2 & 357.4 & - \\
\hline & 0.01 & 974 & 385.9 & - \\
\hline & 1 & 614.4 & 607 & 554.7 \\
\hline
\end{tabular}
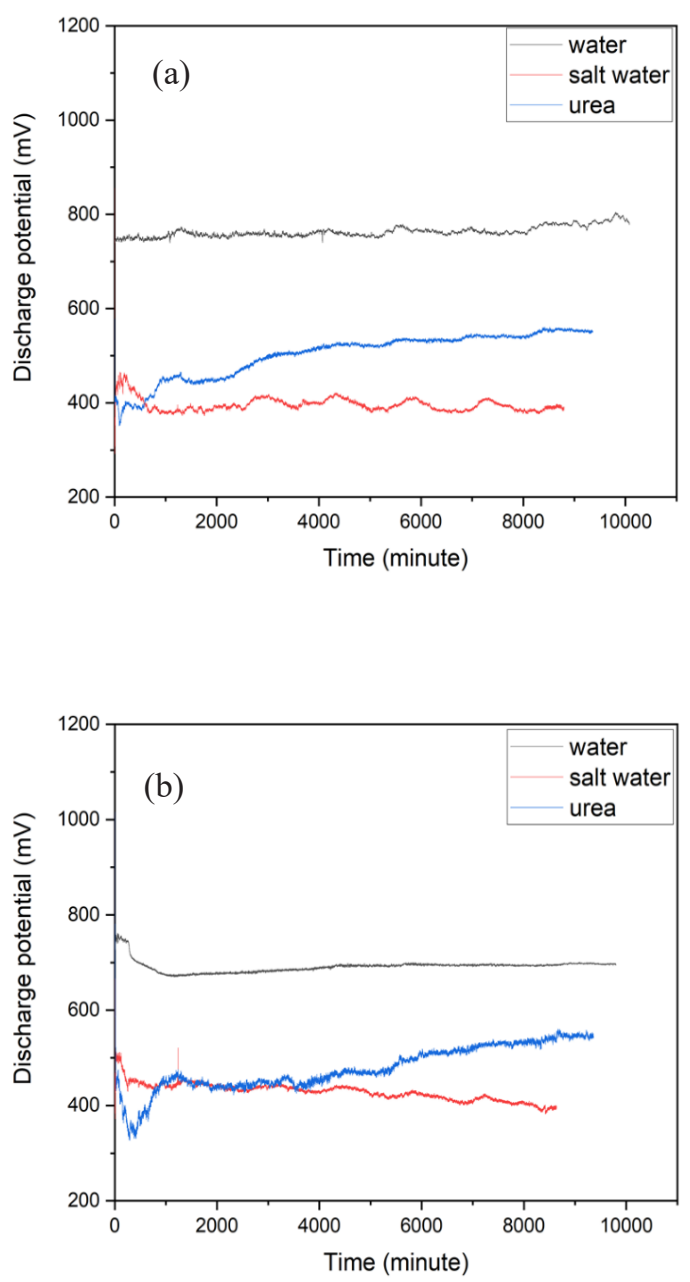

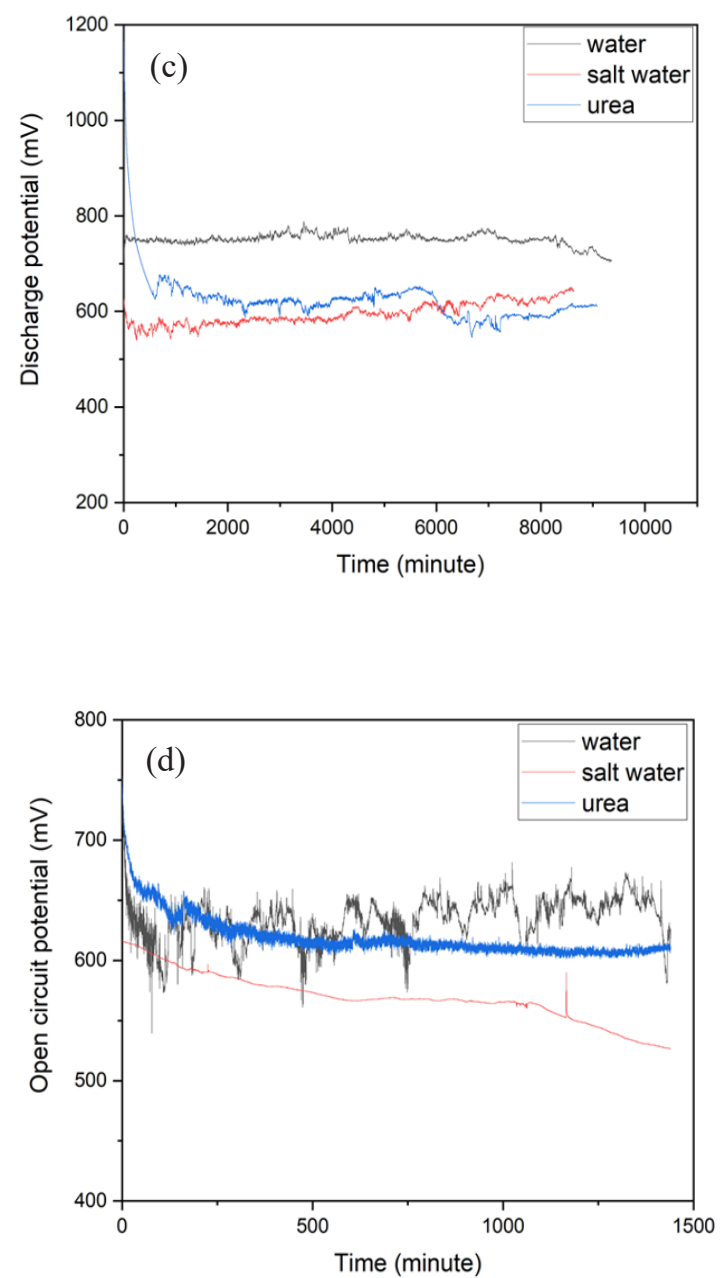

FIGURE 6. Discharge curve of a single cell $\left(\mathrm{Al} / \mathrm{MnO}_{2}\right)$ at (a) 0.001 $\mathrm{mA}$, (b) $0.01 \mathrm{~mA}$, and (c) $1 \mathrm{~mA}$ (d) OCV curves using water, salt water, and urea as electrolytes

\section{CONCLUSION}

In this work, the effects of electrolyte and discharge current of aluminum alloy ( $\mathrm{Al} \mathrm{6061)} \mathrm{anode} \mathrm{in} \mathrm{an} \mathrm{electrolyte}$ activated battery were investigated. The microstructure results showed that the corrosion rate of battery tested in salt water is the highest, followed by urea and water. The potentiodynamic polarization showed that water has the highest negative value of $1.2685 \mathrm{~V}$, followed by urea with the negative value of $-0.91211 \mathrm{~V}$ and salt water with the value of $-0.64843 \mathrm{~V}$. A more negative value is beneficial for the utilization of anode material in the electrolyte activated battery. The galvanostatic discharge showed that salt water had the lowest average potential compared to water and urea. EIS results showed that water has the highest value of charge transfer resistance $\left(R_{t}\right)$ of $394.25 \Omega$ then followed by urea and salt water which are 227.57 and $209.92 \Omega$, respectively. EIS also showed the corrosion mechanism of all three combination is activation-controlled. The higher the value of $R_{t}$, the lower the corrosion rate. From all the physicochemical and electrochemical characterizations, the results showed that water is the best electrolyte among these three electrolytes, however the low discharge potential required a further modification on the anode electrode. A good anode for electrolyte battery should have a balance between of self-corrosion and dissolution.

\section{ACKNOWLEDGEMENTS}

The authors would like to thank Universiti Kebangsaan Malaysia for their financial support for this work through Grant No. RCRP-2016-005 \& PP-SELFUEL-2020.

REFERENCES 
Abdulrehman, T., Yousif, Z.A., Abdulkareem, I., Abdulla, A.M. \& Haik, Y. 2015. Enhancing the performance of $\mathrm{Mg}$ e Al brine water batteries using conductive polymer-PEDOT: PSS. Renewable Energy 82: 125-130.

Brantley, W., Berzins, D., Iijima, M., Tufekçi, E. \& Cai, Z. 2017. 1 - Structure/Property Relationships in Orthodontic Alloys. Orthodontic Applications of Biomaterials: A Clinical Guide. Elsevier: Woodhead Publishing.

Deng, M., Wang, R., Feng, Y., Wang, N. \& Wang, L. 2016. Corrosion and discharge performance of $\mathrm{Mg}-9 \% \mathrm{Al}-$ $2.5 \% \mathrm{~Pb}$ alloy as anode for seawater activated battery. Transactions of Nonferrous Metals Society of China 26(8): 2144-2151.

Feng, Y., Xiong, W., Zhang, J., Wang, R. \& Wang, N. 2016. Electrochemical discharge performance of the $\mathrm{Mg}-\mathrm{Al}$ $-\mathrm{Pb}-\mathrm{Ce}-\mathrm{Y}$ alloy as the anode for $\mathrm{Mg}$ - air batteries. Journal of Materials Chemistry A: Materials for Energy and Sustainability 4(22): 8658-8668.

Hongyang, Z., Pei, B. \& Dongying, J.U. 2009. Electrochemical performance of magnesium alloy and its application on the sea water battery. Journal of Environmental Sciences 21: S88-S91.

Ilya, J., Chea, C.C., Featonby, D. \& Vitkoczi, F. 2017. Preliminary study on aluminum-air battery applying disposable soft drink cans and Arabic gum polymer. IOP Conference Series: Materials Science and Engineering 237(1): 012039.

Kim, Y., Kim, G.T., Jeong, S., Dou, X., Geng, C., Kim, Y. \& Passerini, S. 2019. Large-scale stationary energy storage: Seawater batteries with high rate and reversible performance. Energy Storage Materials 16: 56-64.

Kim, Y., Kim, H., Park, S., Seo, I. \& Kim, Y. 2016. Na ionconducting ceramic as solid electrolyte for rechargeable seawater batteries. Electrochimica Acta 191: 1-7.

Kobashi, H. \& Oshitani, M. 2009. Primary batteries - reserve systems | Seawater Activated Batteries: Magnesium. Encyclopedia of Electrochemical Power Sources. pp. 156163.

Kushima, A., Koido, T., Fujiwara, Y., Kuriyama, N., Kusumi, N. \& Li, J. 2015. Charging/discharging nanomorphology asymmetry and rate- dependent capacity degradation in $\mathrm{Li}$ - oxygen battery. Nano letters 15(12): 8260-8265.

Leisegang, T., Meutzner, F., Zschornak, M., Münchgesang, W., Schmid, R., Nestler, T. \& Meyer, D.C. 2019. The aluminumion battery: A sustainable and seminal concept? Frontiers in Chemistry 7: 268.

Li, J., Wan, K., Jiang, Q., Sun, H., Li, Y. \& Hou, B. 2016. Corrosion and discharge behaviors of $\mathrm{Mg}-\mathrm{Al}-\mathrm{Zn}$ and $\mathrm{Mg}-\mathrm{Al}-$ Zn-in alloys as anode materials. Metal 6(3): 65.

Li, Q. \& Bjerrum, N.J. 2002. Aluminum as anode for energy storage and conversion: A review. Journal of Power Sources 110(1): 1-10.

Liu, Q., Yan, Z., Wang, E., Wang, S. \& Sun, G. 2017. A highspecific-energy magnesium/water battery for full-depth ocean application. International Journal of Hydrogen Energy 42(36): 23045-23053.

Mokhtar, M., Majlan, E.H., Ramli, W., Daud, W., Ahmad, A. \& Tasirin, S.M. 2018. Effect of ZnO filler on PVAalkaline solid polymer electrolyte for aluminum-air battery applications. Journal of The Electrochemical Society
165(11): 2483-2492.

Mokhtar, M., Zainal, M., Talib, M., Herianto, E., Masrinda, S., Muhammad, W. \& Sahari, J. 2015. Journal of industrial and engineering chemistry recent developments in materials for aluminum - air batteries: A review. Journal of Industrial and Engineering Chemistry 32: 1-20.

Mroczkowska, K.M., Antończak, A.J. \& Gąsiorek, J. 2019. The corrosion resistance of aluminum alloy modified by laser radiation. Coatings 9(10): 672.

Nikseresht, Z., Karimzadeh, F., Golozar, M.A. \& Heidarbeigy, M. 2010. Effect of heat treatment on microstructure and corrosion behavior of A16061 alloy weldment. Materials and Design 31(5): 2643-2648.

Pino, M., Herranz, D., Chacón, J., Fatás, E. \& Ocón, P. 2016. Carbon treated commercial aluminium alloys as anodes for aluminium-air batteries in sodium chloride electrolyte. Journal of Power Sources 326: 296-302.

Pino, M., Chacón, J., Fatás, E. \& Ocón, P. 2015. Performance of commercial aluminium alloys as anodes in gelled electrolyte aluminium-air batteries. Journal of Power Sources 299: 195-201.

Raptis, D., Seferlis, A.K., Mylona, V., Politis, C. \& Lianos, P. 2018. Electrochemical hydrogen and electricity production by using anodes made of commercial aluminum. International Journal of Hydrogen Energy 44(3): 13591365.

Ropital, F. 2011. Advances in Clean Hydrocarbon Fuel Processing: Science and Technology. Environmental Degradation in Hydrocarbon Fuel Processing Plant: Issues and Mitigation. Elsevier: Woodhead Publishing Limited.

Shi, Y., Peng, C., Feng, Y., Wang, R. \& Wang, N. 2017 a. Microstructure and electrochemical corrosion behavior of extruded $\mathrm{Mg}-\mathrm{Al}-\mathrm{Pb}-\mathrm{La}$ alloy as anode for seawateractivated battery. Materials and Design 124: 24-33.

Shi, Y., Peng, C., Feng, Y., Wang, R. \& Wang, N. 2017 b. Enhancement of discharge properties of an extruded $\mathrm{Mg}$ $\mathrm{Al}-\mathrm{Pb}$ anode for seawater-activated battery by lanthanum addition. Journal of Alloys and Compounds 721: 392-404.

Starostin, M., Shter, G.E. \& Grader, G.S. 2016. Corrosion of aluminum alloys Al 6061 and $\mathrm{Al} 2024$ in ammonium nitrateurea solution. Materials and Corrosion 67(4): 387-395.

Tang, J., Li, J., Wang, H., Wang, Y. \& Chen, G. 2019. in-situ monitoring and analysis of the pitting corrosion of carbon steel by acoustic emission. Applied Sciences 9: 1-19.

Tang, Y., Zheng, S., Xu, Y., Xiao, X., Xue, H. \& Pang, H. 2018. Advanced batteries based on manganese dioxide and its composites. Energy Storage Materials 12: 284-309.

Vuorilehto, K. 2003. An environmentally friendly wateractivated manganese dioxide battery. Journal of Applied Electrochemistry 33: 15-21.

Wang, N., Wang, R., Peng, C. \& Feng, Y. 2014a. Enhancement of the discharge performance of AP65 magnesium alloy anodes by hot extrusion. Corrosion Science 81: 85-95.

Wang, N.G., Wang, R.C., Peng, C.Q., Hu, C.W., Feng, Y. \& Peng, B. 2014b. Research progress of magnesium anodes and their applications in chemical power sources. Oral Oncology 50(10): 2427-2439.

Wen, L., Yu, K., Xiong, H., Dai, Y., Yang, S., Qiao, X. \& Fan, S. 2016. Composition optimization and electrochemical 
properties of $\mathrm{Mg}-\mathrm{Al}-\mathrm{Pb}-(\mathrm{Zn})$ alloys as anodes for seawater activated battery. Electrochimica Acta 194: 40-51.

Yu, K., Xiong, H., Wen, L., Dai, Y., Yang, S., Fan, S. \& Qiao, X. 2015. Discharge behavior and electrochemical properties of $\mathrm{Mg}$ i Al í Sn alloy anode for seawater activated battery. Transactions of Nonferrous Metals Society of China 25(4): 1234-1240.

Zhang, Y., Wu, Y., Chen, D., Wang, R., Li, D., Guo, C. \& Nash, P. 2017. Surface \& coatings technology micro-structures and growth mechanisms of plasma electrolytic oxidation coatings on aluminium at different current densities. Surface \& Coatings Technology 321: 236-246.

Priyathashiny Pongali, Wai Yin Wong \& Kean Long Lim* Fuel Cell Institute

Universiti Kebangsaan Malaysia

43600 UKM Bangi, Selangor Darul Ehsan

Malaysia

Alvie Sin Voi Lo

Faculty of Science and Natural Resources
Universiti Malaysia Sabah Jalan UMS, 88400, Kota Kinabalu, Sabah Malaysia

Sammy Lap Ip Chan

School of Materials Science and Engineering

University of New South Wales

New South Wales, 2052

Australia

*Corresponding author; email: kllim@ukm.edu.my

Received: 17 August 2020

Accepted: 11 September 2020 